MANNHEIM RESEARCh INSTITUTE FOR THE ECONOMICS OF AGING

\title{
THE EFFECT OF COMPULSORY SCHOOLING ON HEALTH - EVIDENCE FROM BIOMARKERS
}

Hendrik Jürges, Eberhard Kruk and Steffen Reinhold 


\title{
The effect of compulsory schooling on health - evidence from biomarkers
}

\author{
Hendrik Jürges ${ }^{*}$, Eberhard Kruk, and Steffen Reinhold \\ MEA - University of Mannheim \\ L13, 17 \\ 68131 Mannheim \\ Germany \\ Tel. +49-621-181-3519 \\ Fax: +49-621-181-1863
}

June 2009

\begin{abstract}
Using data from the Health Survey for England and the English Longitudinal Study on Ageing, we estimate the causal effect of schooling on health. Identification comes from two nation wide increases in British compulsory school leaving age in 1947 and 1973, respectively. Our study complements earlier studies exploiting compulsory schooling laws as source of exogenous variation in schooling by using biomarkers as measures of health outcomes in addition to self-reported measures. We find a strong positive correlation between education and health, both self-rated and measured by blood fibrinogen and C-reactive protein levels. However, we find ambiguous causal effects of schooling on women's self-rated health and insignificant causal effects of schooling on men's self-rated health and biomarker levels in both sexes.
\end{abstract}

Keywords: Health, Compulsory schooling, Biomarkers, Regression discontinuity

JEL-Classification: I12, I20.

\footnotetext{
*Corresponding author. juerges@mea.uni-mannheim.de
} 


\section{Introduction}

In this paper, we aim at contributing to the growing literature on identifying the causal link between education and health. Theoretically, the economic literature has identified causal effects of education on health through at least four plausible channels: (a) just as in the labor market, education raises efficiency in health production (raises the marginal productivity of inputs), i.e. it increases an individual's productive efficiency (Grossman 1972); (b) education changes inputs into health production (through information) and thereby increases allocative efficiency (Rosenzweig \& Schulz 1981); (c) education itself changes time preference (and thus inputs into health production) because schooling focuses students' attention on the future (Fuchs 1982, Becker \& Mulligan 1997); (d) education has an indirect effect mediated through higher income, occupational status, and access to better housing, or environmental conditions.

Numerous studies have indeed documented a strong positive empirical association between education and health (see the surveys by Cutler \& Lleras Muney 2008 or Grossman 2006). Interpretation of this correlation as causal is difficult, however, because education is most likely an endogenous variable, for instance because unobserved variables such as time preferences possibly drive both education and health behavior decisions, or because health (at younger ages) affects educational achievement (reverse causation). Recent empirical work addresses causality issues head on using natural experiments such as exogenous changes in compulsory schooling laws for identification. ${ }^{1}$

In this paper, we study the possible causal link between education and health using two nationwide changes in minimum school leaving age in England in 1947 and 1973 as sources of exogenous variation. In those years, minimum school leaving age was raised from from 14 to 15 (affecting birth cohorts born in or after April 1933) and from 15 to 16 years (affecting birth cohorts born in or after September 1957), respectively. Both reforms have already been used in previous studies to study causal effects of education on wages (Oreopoulos 2006, Devereux and Hart 2008), or political participation (Milligan et al. 2004). We are also not the first to exploit this reform for causal analyses of education on health outcomes (see e.g. Oreopoulos 2006, Clark \& Royer 2008, Silles 2009, Lindeboom et al. 2009). Oreopoulos (2006) finds positive effects of this reform on self-rated health (and a range of labor market

\footnotetext{
${ }^{1}$ See e.g. Adams (2002), Albouy \& Lequin (2008), Arendt (2005), Clark \& Royer (2008), Lleras-Muney (2005) Oreopoulos (2006), and Silles (2009).
} 
outcomes) in the combined UK General Household Surveys from 1983 to 1998. Clark \& Royer (2008) use vital statistics and data from the Health Survey for England and find very small - not always significant - positive effects of the reform on mortality, self-rated health or health behaviors. Critique concerning the external validity of such studies and their value for current policy recommendations could come from the fact that cohorts affected by the reform were born some 75 years ago. Education policy today might have a different effect. Silles (2009) also exploits the increase in mandatory school leaving age in 1973 that affected cohorts born in or after September 1957. Comparison of the effects of the two reforms that were 26 years apart gives at some indication whether (causal) education effects on health are stable over time. In fact, using data from the UK General Household Surveys, Silles (2009) finds positive significant causal effects of education on self-rated health for the 1947 reform but not for the 1973 reform.

While we analyze the effect of the same reforms as others, partly using the same data, we deviate from these papers in two important ways. First, in contrast to earlier studies, all of our estimations will be sex-specific. As we show below, the education reforms have affected education decisions of men and women differently, and this can have a crucial effect on causal estimates of education effects based on these reforms. The second innovation of our paper is to complement the earlier analyses - that have mainly relied on self-reported health measures - by using biomarkers as health outcomes. One important recent development in survey research is the integration of biomarkers. Biomarkers are often associated with genetic information, i.e., DNA samples. However, the vast majority of biomarkers currently collected and analyzed are non-genetic: anthropometric measurements (height, weight, waist circumference, lung capacity, grip strength, balance) and blood and saliva samples. The scientific value of collecting such biomarkers in large surveys is promising (National Research Council 2008). First, biomarkers improve the measurement of health. Self-reports of health are subject to considerable under-, over-, or misreporting, depending on the circumstances and dimensions at hand (e.g. Jürges 2007, 2008, Bago d'Uva et al. 2008). Objective information can be used to validate respondents' reports and to study the amount and determinants of under-, over-, or misreporting in population surveys. Self-ratings of health may be subject to reporting bias that is correlated with important determinants of health. Self-reports of health have their own distinct scientific value. For instance, it has been shown that they contain information on health status even after conditioning on objective measures of health (Idler \& Benyamini 1997). Thus, biomarkers should be seen as 
complementary measurements rather than substitutes. However, the value of self-assessments alone as policy outcome measures is less clear. It would be hard to evaluate the benefits of a health care reform, say, that improves self-assessed health but leaves more objective measures of health unchanged.

Second, biomarkers allow studying physiological pathways in the complex relationship between social status and health, providing information on important links that can be used to identify causal relationships. Below, we analyze markers that are known to be risk factors for cardiovascular disease. Thus our analyses allow identifying whether education has a causal effect not only on manifest conditions but also on the risk of developing a disease.

Third, biomarkers provide direct information on pre-disease pathways, in particular by measuring physiological processes that are below the individual's threshold of perception. This could be important to find causal effects of education on the health at younger ages when diseases have not yet become manifest More generally, combined with longitudinal data on individuals, biomarkers help to identify the role of the environment in turning health risks into manifest diseases. The latter points are especially important if education has important indirect effects on health through occupational status and work-related stress (Brunner et al. 1996).

In our analyses, we concentrate on two biomarkers for inflammatory processes: blood fibrinogen, a blood-clotting factor, and blood C-reactive protein (CRP), a protein released into the bloodstream when there is active inflammation in the body. Both have recently gained much interest in the medical literature as predictors of incident cardiovascular disease (for reviews of the literature see e.g. Kamath \& Lip 2003 and Hirschfield \& Pepys 2003). Elevated levels of fibrinogen and CRP have been shown to be strong, independent predictors of weight gain (Duncan et al. 2000), incident diabetes (Pradhan et al. 2001), or incident cardiovascular disease (Ridker et al. 2002, 2003). Whether these associations are causal is still unknown. Still, for the medical practitioner such findings suggests that patients who would benefit most from interventions targeting blood pressure and cholesterol lowering, smoking cessation or exercise promotion, could be identified by blood fibrinogen and CRP levels.

Besides genetic variation, fibrinogen levels have been shown to be positively associated with age, being female, and being a smoker, obese, or physically inactive. Fibrinogen 
concentration has also been shown to be associated with childhood environmental conditions (measured by adult height and parental socioeconomic status), education level (Brunner et al. 1996), and subjective social status (Demakakos et al. 2008). Higher CRP levels have been shown to be associated with higher age, being female, and also with subjective social status (Demakakos et al. 2008).

Our study proceeds as follows. In the next section, we will briefly describe the school reforms analyzed in this paper and their effect on educational attainment. In section 3, we explain the identification strategy (fuzzy discontinuity design) which we use to exploit these reforms. The fourth section describes the data and shows some descriptive results on the correlation between education and self-rated health, blood fibrinogen and blood CRP levels. Section 5 contains the causal estimates and robustness checks. We discuss our results and give conclusions in section 6 .

\section{Institutional background}

In this section, we will briefly describe the most salient aspects of the changes in schooling laws in Britain that we use for identification. The first change in minimum school leaving age analyzed in our paper was part of the 1944 Education Act and took effect on April $1^{\text {st }}, 1947$. Individuals who were born before April 1933 and who turned 14 before the law change could leave school at the end of the term in which they turned 14 (the UK school year is divided into three terms). Individuals who were born in April 1933 or later and who turned 14 after the law change had to stay in school until the end of the term in which they turned 15, i.e. at least until Summer 1948. This law change had a dramatic effect on the average age at which British pupils left school (see below). In 1973, minimum school leaving age was again raised, from 15 to 16, by the Raising of the School Leaving Age (ROSLA) Order of 1972. This reform affected pupils born on or after September $1^{\text {st }} 1957$.

Figure 1 illustrates the effect of the 1947 and 1973 changes in compulsory school leaving age on educational attainment (these data are from the combined HSE samples described below). For both reforms, we show the percentage of pupils who have finished school at age 14, 15 and 16, respectively, for birth cohorts born 5 years before to 5 years after the first cohort that was affected by the reform. Among pre-1947 reform cohorts, roughly 60 percent left school at the age of 14 , and 10 percent left school at age 15 . The relationship between the two 
proportions practically reverses after the reform. About 55 percent of each cohort left school at age 15.7 percent of those immediately affected by the reform still left school at age 14 . In principle, nobody born in or after April should report a school leaving age of 14 . This is not the case however, which might be due to misreporting, individual non-compliance, or districts failing to provide sufficient school places immediately after the reform - as pointed out by Clark \& Royer (2008). Over the years, this proportion decreased to 4 percent for the cohorts born after the first quarter of 1933. It is interesting to note the effect of the reform on the average number of years in school (see Figure 2). Education has been on a secular increase for men and women. The 1947 reform has boosted this increase further but the increase at the discontinuity was much larger for women than men. Average school leaving age has jumped by about 0.4 years for men and 0.6 years for women.

--- about here Figures 1 and 2 ---

The pattern of change we find for the 1973 reform is different (see lower panel of Figure 1). Of the pre-1973 reform cohorts, 32 percent on average left school at the age of 15 . A similar proportion, 30 percent, left school at the age of 16 . After the reform, the percentage of pupils leaving at age 16 increased to about 52 percent whereas the proportion of those leaving at age 15 became negligible (roughly 7 percent). During the observation period, the average number of years in school (Figure 2) was fairly stable for men, except for the jump of about 0.35 years induced by the 1973 reform. Education of women was still on the increase and the 1973 reform apparently only had a fairly small effect on average years in school.

Based on the described reforms, we aim at identifying the effect of schooling on health by comparing health outcomes of individuals born until March 1933 to those born in or after April 1933 and of those born in or after September 1957 to those born until August 1957. The assumption underlying our empirical approach that allows identifying a causal effect, and which is described in the next section, is that there are no unobserved cohort-level determinants of health that have changed at the time of the reform.

\section{Econometric method}

The nature of the two reforms analyzed in this paper clearly makes them a candidate for a regression discontinuity design (RD). The idea of the $\mathrm{RD}$ approach is that the probability of 
receiving a particular treatment (here: an additional year of education) is a discontinuous function of a continuous treatment-determining variable (here: day of birth). This allows to estimate causal effects of the treatment by comparing outcomes (here: health) for individuals just below and just above the treatment threshold (for an overview of recent econometric developments concerning the RD design see Imbens \& Lemieux (2008) and Lee \& Lemieux (2009)). As documented in the preceding section, the treatment in our application is not purely assigned on the basis of the birth date (i.e. the treatment is under partial control of the individuals). After both reforms, some individuals left school at younger ages than the legal school leaving age (at least so they said in the HSE and ELSA). They thus did not receive the treatment after the threshold date, i.e. the probability of treatment did not jump to 1 . In such cases, a so-called "fuzzy" RD (FRD) design becomes appropriate. In case of a binary treatment, the FRD design is basically a Wald estimator. To see this, let $Y$ be the health outcome, $X$ be the date of birth as treatment-determining variable, $W$ be the treatment received, and value $c$ be the threshold value of the treatment-determining variable, then the FRD estimator can be written as (Imbens \& Lemieux 2008):

$$
\tau_{F R D}=\frac{\lim _{x \downarrow_{C}} E(Y \mid X=x)-\lim _{x \uparrow_{C}} E(Y \mid X=x)}{\lim _{x \downarrow_{C}} E(W \mid X=x)-\lim _{x \uparrow_{C}} E(W \mid X=x)}
$$

Under certain assumptions (monotonicity or no defiers, i.e. individuals do not leave school earlier because of the reform), education does not, and by taking limits from above and below the threshold value c, $\tau_{F R D}$ identifies the average treatment effect on the treated (averaged across all compliers at the threshold $c$ ). Take the 1947 reform as an example. If sample size was no problem, then equation (1) would tell us to just compare the average health of all individuals born on April $1^{\text {st }} 1933$ with outcomes of all individuals born on March $31^{\text {st }} 1933$ and divide the difference (the numerator) by the difference in average school leaving ages of those two groups of individuals (the denominator).

However, sample size at the discontinuity almost always is a problem. For instance, in our pooled sample described below, we have 54 individuals each born in March and April 1933 with valid fibrinogen values. Finding significant health effects for such small samples is virtually impossible. The task is thus to appropriately estimate average outcomes and treatments at the discontinuity using observations that are further away from the discontinuity, for instance using all observations that are born four years before and after the threshold. The 
key issue here is how to model long-run relationships between the treatment-determining variable and the outcomes. Imbens \& Lemieux (2008) suggest local linear regression, i.e. linear regressions of $Y$ on $x$ separately for individuals below and above the threshold (within some bandwidth $h$ ) and to predict $Y$ at the threshold value of the treatment-determining variable. (Analogous regressions are done for $W$ ). Alternatively, one can choose some parametric form, such as a fourth-order polynomial. Lee \& Lemieux (2009) recommend not to rely on a single specification. Alternative specifications, using local-linear regression and global approaches, that yield similar results lend credibility to the RD approach. One practical issue is to choose the appropriate bandwidth for the local or global regression. When we show our results we arbitrarily choose one bandwidth (4 years) and estimate local linear regressions. We present results using alternative bandwidths and alternative parametric specifications in Section 5 as part of our robustness checks. Another issue, recently discussed in Lee \& Card (2008), is the fact that with month of birth data, i.e. with a discrete treatmentdetermining variable, the limits shown in equation (1) do not exist. As suggested in Lee \& Card, we account for this fact by computing cluster-corrected standard errors, where clusters are given by each value of the treatment-determining variable (month of birth).

\section{Data and descriptive results}

We use data from the Health Surveys for England (HSE) 1993, 1994, 1998 to 2000, and 2003 to 2006 and the English Longitudinal Study on Ageing (ELSA) 2006. The Health Survey for England is an annual health interview survey of around 15,000 to 20,000 respondents in England conducted by the National Centre for Social Research (separate surveys are available for Scotland and Wales). The English Longitudinal Study on Ageing is an ongoing multidisciplinary panel survey of the older population covering around 12,000 respondents in England. It was started in 2004 based on a sample that was derived from three waves of the Health Surveys for England 1998, 1999 and 2001. Part of our ELSA sample consists of respondents already present in the HSE 1998 and 1999, i.e. some individuals are represented twice in our data. We are, however, not able to identify these respondents present in both data sources. In fact, the data use contract explicitly forbids re-identification of such respondents. The data are distributed by the Economic and Social Data Service (ESDS). We restrict our analyses to the survey years listed above because only data from these years contain information on blood fibrinogen and CRP levels. Biomarkers are collected during nurse visits 
after the actual health interview and include not only blood samples but also anthropometric measurements, blood pressure measurements, and saliva samples.

We further restrict our analytical samples in two ways. First, for most of our analyses we use only birth cohorts that are born at most 4 years before and after the two relevant thresholds April 1933 and September 1957 (we lift this sample restriction when we try different bandwidth in our regression discontinuity approach). Second, we eliminate from our sample all respondents who were not born in England, Wales, or Scotland, i.e. respondents for whom it is unclear if they have been in the British school at the time of the reform.

We use two main health outcome measures: blood fibrinogen levels and blood C-reactive protein levels: For comparison with earlier studies we also analyze effects of education on self-rated general health (dichotomized to good/poor health). The blood fibrinogen level is measured in grams per liter and the blood C-reactive protein level is measured in mg per liter. One difficulty with combining biomarkers spanning more than 10 years of data collection is that measurements are not necessarily comparable across years due to changes in collection methods, assays, and laboratories. Indeed, the HSE user guide explicitly warns against comparing biomarker levels over time. In order to make our data compatible for use in a pooled data set, we have standardized all measurements to have the means and standard deviations of the 1998 measurement.

As discussed in the introduction, higher levels of fibrinogen and CRP indicate the presence of inflammatory processes and have been shown to be associated with higher risks of obesity, diabetes and cardiovascular disease. In accordance with other studies analyzing the relationship of socio-economic status and CRP levels, we exclude cases with a CRP level of over10 mg/L from further analysis. In cases of acute inflammation CRP values can increase by as much as 10,000-fold. High CRP values might thus relate to acute inflammation and not be informative of chronic pathogenic processes (Pearson et al., 2003). Including these cases in the data potentially biases our results.

In our regression analyses shown below, we will use information on adult height to control for both the economic and disease environment in childhood, which can have long-lasting effects on adult health. Adult height reflects the accumulated nutritional experience during childhood including the fetal period, and is shown to have considerable predictive power both for 
morbidity and mortality (see Fogel 1997, Deaton 2007) and also educational outcomes (Magnusson et al. 2006). Controlling for height hence serves two purposes. First, in the descriptive (OLS) regressions, inclusion of height captures the effect of a potentially important third factor (childhood conditions) driving both adult health and educational outcomes. We should again stress at this point that adult height is practically determined before schooling decisions are made, either by its genetic component or by early childhood environment. Second, in the instrumental variables regressions, inclusion of height also helps controlling for unobserved cohort effects that cannot readily be captured by (local) polynomial cohort trends. Note that the first cohort affected by the first reform was born in 1933, i.e. in the immediate aftermath of the great depression, and it is a priori unclear if and how the depression has effected childhood environment (and thus adult health and education) of the cohorts in our analytical sample. For instance, we find some indication in our data that, also after controlling for cohort trends, children born after March 1933 are slightly taller than older cohorts.

--- about here Table 1 ---

Table 1 briefly describes the analytical samples, separately for the 1947 reform cohorts (born between 1929 and 1937) and the 1973 reform cohorts (born between 1953 and 1961). Columns (1) to (4) show descriptive statistics for the full samples. The average age at survey in older cohorts is 66 years for men and 67 years for women. In the younger sample it is 41 years for both sexes. The average age at which respondents left school has increased substantially from 15.4 years for the older cohorts to 16.7 years for the younger cohorts. The proportion of respondents who reported to be in poor health is 36 percent (men) and 34 percent (women) among the 1947 reform cohorts and among the 1973 reform cohorts. Log fibrinogen and log CRP levels are slightly higher among women and lower in the younger cohorts. Table 1 also shows that both men and women in the 1947 reform cohorts are on average 4cm shorter than men and women in the 1973 reform cohorts.

The number of observations with valid information on fibrinogen and CRP levels is substantially lower than the full samples. Not all HSE respondents have given consent to be visited by a nurse or to have blood samples taken. Sometimes, respondents are not eligible for blood testing because of medical or other reasons. Further, it is sometimes not possible to identify blood values from samples taken from respondents and finally, some results are 
invalid for analysis because respondents take medication that affects blood fibrinogen or blood CRP levels. Especially non-compliance on the part of the respondents or medical ineligibility might be a cause of worry due to selection effects. Rather than deal with this issue formally at this stage, we simply look at differences in average sample characteristics between those with valid fibrinogen/CRP levels and the full samples. As it turns out, the full sample and the sample with valid blood test data are very similar as far as observable characteristics are concerned (a more detailed analysis of participation in the nurse visit is presented in the Appendix). Still, to get some information on the possible effect of differences between the full sample and the nurse visit sample on our regression results, we also estimated all regressions using self-rated health as outcome but restricting the sample to those also participating in the nurse visit. We find only small changes in our results, so that we believe that sample selectivity should not be a cause of concern.

\section{Relationship between self-rated health and biomarkers}

To illustrate the correlation of traditional health measures such as self-rated health and the biomarkers used in the present study, Table 2 shows average levels of (log) blood fibrinogen and (log) blood CRP for different levels of self-rated health, separately for the two analytical cohorts. Within each cohort and for both measures, we find a clear gradient with higher levels of fibrinogen and CRP for respondents who self-report worse health (fibrinogen and CRP levels are also highly correlated with each other, $\mathrm{r}=0.50$ ). The younger cohorts generally have lower values than the older cohorts even when reporting the same level of self-rated health, reflecting lower risk of cardiovascular disease. Members of the younger cohort who report to be in poor health have higher CRP levels than members of the older cohorts reporting to be in good health. Table 2 also documents the correlation between adult height and health measured by biomarkers. Individuals in the top half of the cohort-sex-specific height distribution generally have lower blood fibrinogen and CRP levels than individuals in the lower half. 
Table 3 shows the descriptive relationship between education (measured as the age when the respondent left school) and the three health outcomes: self-rated health (again dichotomized to good versus poor), log fibrinogen level, and log CRP level. In each regression, we control for cohort (year and month of birth), season of birth, height and sex. We also control for survey year to account for possible unobserved differences across survey.

--- about here Table 3 ---

For each of our measures, the results shown in Table 3 provide evidence for a significant association between education and health. Leaving school one year later is associated with about a 5 to 6 percentage point decrease in the probability of reporting poor general health in the older cohorts and a 3 to 4 percentage point decrease in the younger cohorts. When the sample is restricted to respondents participating in the nurse visit, these associations become somewhat smaller. Also, controlling for cohort, season of birth, height, and survey year reduces the strength of the association. Still, the slope of the education-self assessed health gradient is fairly large. It corresponds to more than ten years of age. Our findings for subjective health are corroborated by the more "objective" biomarkers. Each year of education is associated with a reduction in the blood fibrinogen level by 1.5 (women) to 1.9 percent (men) in the older cohorts and by between 1.8 percent (men) and 2.1 percent (women) in the younger cohorts. Controlling for covariates reduces this association but it remains highly significant. The effect size corresponds to about 2 to 3 years of age for men and women, respectively, i.e. the effect size is somewhat smaller than for self-rated health. For log CRP levels, effect sizes are in the range of about 3 years of age.

\section{Regression-discontinuity design results}

The findings described in the preceding section reveal significant and partly sizeable associations between education and various measures of health. In this section we study whether this association is causal. As described above, we make use of two general increases in the minimum school leaving age in 1947 and 1973 that affected all cohorts born in or after April 1933 and September 1957, respectively. 
Results of instrumental variables regression for the fuzzy discontinuity design are shown in Table 4. The first stage parameter shows the effect of the treatment dummy on the average school leaving age within the estimating samples. Here we find considerable differences between men and women and reform cohorts. In line with our graphical analysis in section 2, we find that the 1947 reform had a stronger effect on the education of women than on the education of men. In 1973, the effect was slightly stronger for men. First stage F-statistics (for the instrument) are larger or close to 10 for all regressions except one, indicating that our results do not suffer from a weak instrument problem.

Turning to the FRD parameters, we find that education has a mixed effect on health selfratings. For men in the 1947 reform cohort, the point estimate is plus 2 percentage points, indicating that education might actually harm health. However, the standard error is 15 times as large as the one we get for the OLS estimate in Table 3. Statistically, the 2 percentage points are neither different from zero nor different from the OLS estimate of minus 5 percentage points. For men in the 1973 reform cohort, our IV point estimate is negative and somewhat larger than the OLS coefficient, but again, it is neither different from zero nor different from the OLS coefficient. For women in the 1947 cohort, we obtain an IV estimate of minus 7 percentage points, i.e. a larger effect than OLS, that is statistically different from zero. In contrast, in the 1973 cohort, we find an implausibly large positive effect of education on the probability of reporting poor health. Overall, although most of these results are not inconsistent with a positive causal effect of education on health, it does also not lend much credibility to such an assertion.

Similar to health self-assessments, we do not find convincing evidence for a significant causal effect of education on biomarker levels. Estimates for log fibrinogen levels have mixed signs and are never significantly different from zero. The coefficients for log CRP levels are negative throughout, indicating a positive effect of education on health. Effect sizes are in the vicinity of the OLS estimates - but not significantly different from zero - for men in both reform cohorts and for women in the younger reform cohort. For women in the 1947 reform cohorts point estimates are much larger than OLS estimates. Again, given the large standard errors of our estimates, a Hausman test would not reject the assumption of exogeneity of education. 


\section{Robustness checks}

We now discuss robustness checks on our results presented in the preceding section.

Following the recommendations in Lee \& Lemieux (2009),we primarily test the robustness of our results with respect to the bandwidth around the discontinuity and the functional form of the relationship between the outcome and the treatment-determining variable. Another check is to restrict our sample to respondents with either 14 or 15 years of education in case of the 1947 reform and 15 or 16 years of education in case of the 1973 reform. Among these respondents, the reforms had the most impact on years in school, so that restricting the sample will increase the strength of our instrument.

Our first robustness check is to estimate the FRD parameters using local linear regression and varying the bandwidth from one year to eight years (in half year steps). The results are shown in Table 5. With the exception of very small bandwidths which lead to imprecise estimates due a substantial loss of information, the results appear to be qualitatively robust to changing the bandwidth (beginning at about $h=2.5$ years). However, effect sizes appear to become smaller in absolute value when the bandwidth is increased but this does not necessarily affect statistical significance because estimates also get more precise.

Changes in the size of the estimates suggest that results might be sensitive to how one models non-linearities in cohort effects. We have thus also experimented with alternative specifications using polynomial cohort trends of varying degrees on samples of varying bandwidths (see Table 6). This exercise essentially confirms our findings based on local linear regressions.

Regression results based on the restricted samples are shown in Table 7. Notably, whereas the association between years in school an health usually gets larger (as indicated by the OLS regression parameters also reported for comparison purposes), it partly loses significance. This might not only be due to smaller sample sizes, but also due to less variation in the education variable. 


\section{Discussion}

In this paper we use data from several rounds of the Health Survey for England and the English Longitudinal Study on Ageing to estimate the causal effect of education on health. Our identification comes from two increases in mandatory school leaving age in 1947 and 1973. We are not the first to exploit these reforms for causal analyses in a regression discontinuity approach. However, the specific contribution of our paper is the use of biomarkers (blood fibrinogen and C-reactive protein) in addition of health self-reports as health outcome measures. We do not argue that biomarkers represent "better" or "more precise" measures of health. Rather, we use them as indicators of health that are complementary to subjective measures such as self-rated health. We analyze blood fibrinogen and blood C-reactive protein because high levels in each are known risk factors for cardiovascular disease. Thus our analyses allow identifying whether education has a causal effect not only on manifest conditions but also on the risk of developing a disease.

While education is clearly correlated with lower levels of fibrinogen and C-reactive protein (indicating worse health and higher risk of cardiovascular disease for respondents with a smaller number of years in school), our results contain no evidence for a significant causal effect of education on the examined biomarkers. However, we find some evidence for an effect of education on self-rated health, which we also analyzed for comparison purposes, among women. A puzzling finding in this context is that education appears to cause poor health in the younger reform cohorts.

Overall, our results are only partly in line with earlier studies analyzing the effect of the 1947 and 1973 UK education reforms on health outcomes. For instance, one earlier study using the same data set and exploiting the 1947 reform only (Clark \& Royer 2008) finds no significant effect of education on self-rated health. This is most likely due to the fact that - in contrast to Clark \& Royer (2008) - we perform separate analyses for men and women. Pooled analyses of our data would as well yield insignificant effects and lead us to conclude that there is only weak evidence for a causal effect of education on subjective health. Earlier work using different data but exploiting the same reform, such as Oreopoulos (2006) or Silles (2009) generally finds significant positive effects of education on self-rated health. With respect to more "objective" health measurements (log fibrinogen and CRP blood levels), our finding of no education effect confirms the findings in Clark \& Royer (2008) (looking at BMI and blood 
pressure) but is at odds with other studies using objective outcomes such as mortality (LlerasMuney 2005).

Currently, we can only speculate about the reasons for the differences in results across different studies that all use credible identification strategies. Although a causal effect of education on health (both direct and indirect) is theoretically plausible, we believe that there are a couple of reasons why the effect may actually be hard to identify in observational studies. As other authors, we use regression discontinuity in connection with changes in compulsory schooling for identification. It is well known that RD estimators have good internal validity but that external validity is a problem. For instance using our fuzzy RD design, we are (only) able to identify local treatment effects, i.e. for compliers at the cut-off date. The main effect of the reforms studied in the present paper on education was to keep those who wanted to quit as early as possible in school for one more year. One important question is what has been learned in this one year? There is some evidence that this year had some positive effect on the wages of the affected cohorts (Oreopoulos 2006, Devereux \& Hart 2008), i.e. something has been learned and people have become more productive in the labor market (the higher income apparently had no sizeable impact on health). One explanation for the absence of an effect on objective measures of health is that what needs to be learned to make individuals more productive producers of their own health is different from skills that are valued at the labor market. It is likely that the emerging literature on health literacy sheds more light on this issue (Nutbeam 2008).

Another reason why we may not find good evidence for a causal effect of education on health measured by biomarkers is that our samples are limited to individuals born shortly before and after the relevant cut-off dates for being affected by the reforms. The reason not to choose too wide intervals is obvious. The more birth cohorts are included, the harder it becomes to maintain the assumption that no unobserved factors that influence health have changed in parallel to the reform. One example for such unobserved factors affecting the validity of the instrument is medical progress. Put differently, the instrument loses validity when the sample is extended too far because the exclusion restriction does no longer hold. Of course, by including (local) cohort trends and adult height we hope to account for unmeasured factors, but the risk that the cohort trend is incorrectly specified rises with the number of cohorts included in the regression. The downside of "staying close" to the discontinuity is that the number of observations may quickly become too small to get precise estimates. This may also 
be one explanation for our non-findings with respect to biomarkers. However, we do find significant effects of education on self-rated health in samples of similar size. The contradiction between results for self-rated health and biomarkers could thus also be due to differential reporting styles of respondents of different education levels. This issue has raised some attention in the recent literature (e.g. Bago d'Uva et al. 2008, Jürges 2008,), but cannot be solved in the present paper.

Finally, it must also be noted that our parameters only identify the effect of education for compliers to the two specific reforms of raising mandatory school leaving age. Interventions at other stages of the life-cycle might have more systematic causal effects on health. For instance, a recent strand of the human capital literature has stressed the importance of early childhood education for the development of cognitive and non-cognitive skills (Cunha et al. 2006). If early childhood education changes the whole lifetime path of human capital accumulation, early interventions might substantially improve health, while later life interventions like increasing the number of school years remain largely ineffective. 


\section{Appendix: Nurse visits and selectivity of the biomarker samples}

In this appendix, we look at possible differences between individuals with valid measurements for blood fibrinogen and blood CRP and the full HSE samples. A non-valid blood fibrinogen or CRP level measurement can have a variety of reasons and can essentially be described as a multi-stage process. To get a valid blood sample, the following conditions have to be fulfilled. First, the respondent has to agree to the nurse visit. Second, the nurse visit actually has to take place. Third, the respondent has to be scheduled for the blood sample. For instance, in 1998 respondents younger than 18 were not asked for a blood sample. Fourth, the respondent is not ineligible for blood sampling due to medical reasons (pregnant women, people with clotting or bleeding disorders, and people with a history of fits or convulsions). Fifth, respondents have to agree to have their blood drawn. Sixth, the nurse has to be successful in drawing blood and seventh, the laboratory has to be successful to determine the fibrinogen and CRP levels.

To illustrate the relative importance of various reasons for not obtaining a valid blood sample, we focus on the 1998 round of HSE. Of 15,447 respondents 18 or older, only 1,011 or 6.5 percent refused a nurse visit at the time of the individual interview. The main reasons given for the refusal were that respondents had already given enough time for the survey (25 percent), had enough medical tests recently (19 percent), were not interested (18 percent) or were too busy (17 percent). Of the 14,436 respondents who agreed to the nurse visit, 9 percent refused the nurse visit later. Of the 13,197 respondent visited by a nurse, 6 percent were not scheduled for the blood sample due to medical reasons and 10 percent refused the blood sample. The main reasons given for refusing the blood sample were fear of needles (60 percent), recently had a health check (20 percent), and previous difficulties with venepuncture (16 percent). For 12 percent of the 11,238 respondents consenting to have their blood drawn, no usable samples to determine fibrinogen levels could be obtained by the nurse (numbers vary a little bit for CRP). The number of successfully determined blood fibrinogen levels was 9,913 but 607 cases were excluded from further analysis because respondents took medication affecting fibrinogen levels (this restriction does not apply to CRP levels). Eventually, 60 percent of the age-eligible sample have usable data on blood fibrinogen levels and 67 percent have usable information on blood CRP levels. 
It is beyond the scope of this appendix to analyze the empirical determinants for nonparticipation in the nurse visit or the blood sampling in much detail. Some multiple regression analyses are shown Table A1 which contains the results of probit regressions explaining the probability of participating in the nurse visit and agreeing to the blood sample (conditional on participating in the nurse visit) for our 1947 and 1973 reform cohorts. We estimate a separate regression for each reform cohort. The coefficients reported represent marginal effects..

First we note that across the four survey years, participation rates for nurse visits and conditional participation in the blood sample are close to 90 percent for each reform cohort. Second, demographic and health variables are jointly significant only as explanatory variables for agreeing to the blood sample, not for agreeing to the nurse visit per se. We find that women are generally less likely to participate in nurse visits and blood sampling. Education appears to have mixed effects on the probability to participate in nurse visits and blood sampling. We find a significant positive effect of 1.1 percentage points per year only on the willingness of giving blood in the younger sample. Further, they have opposite signs in both samples. Being in good health has a positive effect on participation in the blood sample. A more detailed analysis of the reasons for refusing, by self-rated health status, reveals that those in poor health were much more likely to have had a recent blood test and that they were currently too ill, whereas those in good health were more likely to express a fear of needles. Finally, we note that willingness to participate in the nurse visit was particularly low in the 1999 survey.

Overall, our regression results suggest a certain degree of selectivity of our biomarkers samples with respect to both health and education so that sample selection bias is a potential problem. Considering the subject of our analysis, it would of course be hard to find valid exclusion restrictions for health and education to estimate a sample selection model. To deal with possible selection biases we check whether we find any differences in regression results for self-rated health when using the full sample and when using the selective sample of respondents for which we have valid blood measurements. As noted in the text, we find only small changes in our results, so that we believe that sample selectivity should not be a cause of concern. 


\section{References}

Adams, S.J. (2002), Educational attainment and health: evidence from a sample of older adults. Education Economics, 10, 97-109.

Arendt, Jakob (2005), Does education cause better health? A panel data analysis using school reform for identification. Economics of Education Review 24, 149-160.

Albouy, V., Lequien, L. (2008), Does compulsory education lower mortality? Journal of Health Economics. doi:10.1016/j.jhealeco.2008.09.003.

Bago d’Uva, T., O. O’Donnell \& E. van Doorslaer. (2008). Differential health reporting by education level and its impact on the measurement of health inequalities among older Europeans. International Journal of Epidemiology 37(6), 1375-83.

Becker, G.S. and C.B. Mulligan (1997), “The endogenous determination of time preference”, Quarterly Journal of Economics 112, 729-758.

Brunner E, Davey Smith G, Marmot M, Canner R, Beksinska M, O’Brien J. (1996), Childhood social circumstances and psycho social and behavioural factors as determinants of plasma fibrinogen. Lancet 347, 1008-13.

Clark, Damon \& Royer, Heather (2008), The Effect of Education on Adult Mortality and Health, Evidence from the United Kingdom, Mimeo.

Cunha, Flavio, Heckman, James J. \& Lochner, Lance (2006), Interpreting the Evidence on Life Cycle Skill Formation. Ch. 12 in: Erik Hanushek \& F. Welch (ed.) Handbook of the Economics of Education. Elsevier

Cutler, David, and Adriana Lleras-Muney (2008), Education and Health: Evaluating theories and evidence. In: The effects of social and economic policy on health. Editors: J. Newhouse, R. Schoeni, G. Kaplan, and H. Polack, forthcoming, Russell Sage Press.

Paul J. Devereux, Robert A. Hart (2008), Forced to Be Rich? Returns to Compulsory Schooling in Britain. IZA DP 3305.

Deaton, Angus (2007), Height, health, and development. Proceedings of the National Academy of Sciences 104 (33), 13232-13237

De Walque, Damien (2007), Does education affect smoking behaviors? Evidence using the Vietnam draft as an instrument for college education, Journal of Health Economics, 26, 877-895.

Duncan, Bruce B., Schmidt, Maria Ines, Chambless, Lloyd E. et al. (2000), Fibrinogen, Other Putative Markers of Inflammation, and Weight Gain in Middle-aged Adults-The ARIC Study. Obesity Research 8, 279-286.

Fogel, Robert William (1997), New Findings on Secular Trends in Nutrition and Mortality: Some Implications for Population Theory. In: Handbook of the Population and Family Economics, edited by: M.R. Rosenzweig and O. Stark, Elsevier.

Grossman, Michael (1972), On the concept of health capital and the demand for health. Journal of Political Economy 80 (2), 223-255.

Grossman, Michael (2006), Education and non-market outcomes. In: Handbook of the Economics of Education, edited by: Eric Hanushek and Finis Welch, Elsevier Science.

Hirschfield GM, Pepys MB (2003): C-reactive protein and cardiovascular disease: new insights from an old molecule. Quarterly Journal of Medicine 2003; 96, 793-807.

Idler EL, Benyamini Y. Self-rated health and mortality: A review of twenty-seven community studies. Journal of Health and Social Behavior 1997; 38, 21-37.

Imbens, Guido W. \& Thomas Lemieux (2008), Regression discontinuity designs: A guide to practice. Journal of Econometrics 142 (2008) 615-635.

Jürges, Hendrik (2007), True health vs response styles: exploring cross-country differences in self-reported health. Health Economics 16, 163-178.

Jürges, Hendrik (2008), Self-assessed health, reference levels, and mortality. Applied Economics 40, 569-582. 
Kamath S, Lip GYH. (2003), Fibrinogen: biochemistry, epidemiology and determinants. Quarterly Journal of Medicine; 96, 711-29.

Lee, David S. and David Card (2008), Regression discontinuity inference with specification error. Journal of Econometrics 142, 655-674.

Lee, David S. and Thomas Lemieux (2009), Regression Discontinuity Design in Economics. NBER working paper 14723.

Lindeboom Maarten, Ana Llena Nozal, and Bas van der Klaauw (2009), Parental Education and Child Health: Evidence from a Schooling Reform. Journal of Health Economics 28, 109-131.

Lleras-Muney, Adriana (2005), The relationship between education and adult mortality in the U.S. Review of Economic Studies, 72, 189-221.

Lundborg, Petter (2008), The health returns to education- what can we learn from twins? IZA DP 3399.

Magnusson P., Finn Rasmussen, and Ulf B Gyllensten (2006), Height at age 18 years is a strong predictor of attained education later in life: cohort study of over 950000 Swedish men. International Journal of Epidemiology 35, 658-663.

Milligan, Kevin, Enrico Moretti and Philip Oreopoulos (2004), Does Education Improve Citizenship? Evidence from the U.S. and the U.K. Journal of Public Economics 88, 1667-1695.

National Centre for Social Research; 1993, 1994, 1998-2000, 2003-2006 Health Survey for England. Distributed by the Economic and Social Data Service.

National Research Council (2008), Biosocial Surveys. Washington DC. The National Academies Press.

Nutbeam, Don (2008), The evolving concept of health literacy. Social Science \& Medicine 67, 2072-2078.

Oreopoulos, P., (2006),. Estimating average and local average treatment effects of education when compulsory schooling laws really matter. American Economic Review 96 (1), 152-175.

Panayotes Demakakos, James Nazroo, Elizabeth Breeze, Michael Marmot (2008), Socioeconomic status and health: The role of subjective social status. Social Science \& Medicine 67, 330-340.

Pearson, T. A., Mensah, G. A., Alexander, R. W., Anderson, J. L., Cannon, R. O., \& Criqui, M., et al. (2003), Markers of inflammation and cardiovascular disease: application to clinical and public health practice: a statement for healthcare professionals from the Center for Disease Control and Prevention and the American Heart Association. Circulation, 107(3), 499-511.

Paul M. Ridker, Nader Rifai,, Lynda Rose., Julie E. Buring, \& Nancy R. Cook (2002), Comparison of CReactive Protein and Low-Density Lipoprotein Cholesterol Levels in the Prediction of First Cardiovascular Events. N Engl J Med 347(20), 1557-65.

Paul M Ridker,; Julie E. Buring,; Nancy R. Cook,; Nader Rifai, (2003), C-Reactive Protein, the Metabolic Syndrome, and Risk of Incident Cardiovascular Events. Circulation 107, 391-397.

Pradhan AD, Manson JE, Rifai N, et al. (2001), C-reactive protein, interleukin 6, and the risk of developing type 2 diabetes mellitus. Journal of the American Medical Association 286, 327-334

Rosenzweig, MR and Schulz. TP (1981), Education and Household Production of Child Health. In: Proceedings of the American Statistical Association (Social Statistics Section), 382-387.

Silles, Mary (2009). The causal effect of education on health: Evidence from the United Kingdom. Economics of Education Review 28, 122-128. 
Table 1: Sample description

\begin{tabular}{|c|c|c|c|c|c|c|c|c|}
\hline & \multicolumn{4}{|c|}{ Full HSE/ELSA sample } & \multicolumn{4}{|c|}{ With valid blood sample } \\
\hline & \multicolumn{2}{|c|}{1947 reform cohorts } & \multicolumn{2}{|c|}{1973 reform cohorts } & \multicolumn{2}{|c|}{1947 reform cohorts } & \multicolumn{2}{|c|}{1973 reform cohorts } \\
\hline & Men & Women & Men & Women & Men & Women & Men & Women \\
\hline & (1) & (2) & (3) & (4) & (5) & (6) & (5) & (6) \\
\hline Age at survey & 66 & 67 & 41 & 41 & 66 & 67 & 41 & 42 \\
\hline Age left school & 15.4 & 15.4 & 16.7 & 16.7 & 15.4 & 15.4 & 16.7 & 16.7 \\
\hline Poor health (\%) & 36 & 34 & 17 & 19 & 37 & 35 & 18 & 19 \\
\hline Height $(\mathrm{cm})$ & 172 & 159 & 176 & 163 & 172 & 159 & 176 & 163 \\
\hline Ln(fibrinogen) & & & & & 1.00 & 1.04 & 0.86 & 0.93 \\
\hline $\operatorname{Ln}(\mathrm{CRP})$ & & & & & 0.63 & 0.66 & 0.12 & 0.14 \\
\hline $\mathrm{N}$ & 4787 & 5280 & 5925 & 7252 & 2135 & 2240 & 3074 & 3409 \\
\hline
\end{tabular}


Table 2: Relation between self-rated health, height and biomarker levels

\begin{tabular}{|c|c|c|c|c|c|c|c|c|}
\hline & \multicolumn{4}{|c|}{1947 reform cohorts } & \multicolumn{4}{|c|}{1973 reform cohorts } \\
\hline & \multicolumn{2}{|c|}{ Men } & \multicolumn{2}{|c|}{ Women } & \multicolumn{2}{|c|}{ Men } & \multicolumn{2}{|c|}{ Women } \\
\hline & Fib & CRP & Fib & CRP & Fib & CRP & Fib & CRP \\
\hline & (1) & (2) & (3) & (4) & (5) & (6) & (5) & (6) \\
\hline \multicolumn{9}{|l|}{ Self-rated health } \\
\hline Poor & 1.05 & 0.81 & 1.08 & 0.80 & 0.91 & 0.37 & 1.01 & 0.47 \\
\hline Good & 0.98 & 0.55 & 1.02 & 0.61 & 0.85 & 0.06 & 0.92 & 0.06 \\
\hline abs. t-value & 6.4 & 5.6 & 5.6 & 4.2 & 5.6 & 5.0 & 8.4 & 6.3 \\
\hline \multicolumn{9}{|c|}{$\begin{array}{l}\text { Height (relative to cohort and } \\
\text { sex specific median) }\end{array}$} \\
\hline Below & 1.01 & 0.64 & 1.06 & 0.70 & 0.87 & 0.16 & 0.94 & 0.21 \\
\hline Above & 0.99 & 0.60 & 1.02 & 0.61 & 0.84 & 0.07 & 0.92 & 0.04 \\
\hline abs. t-value & 1.8 & 1.1 & 4.5 & 2.1 & 3.1 & 1.8 & 3.3 & 3.5 \\
\hline
\end{tabular}

Notes: CRP values available in 1998 and 1999 only. 
Table 3: Descriptive (OLS) regressions of health measures on education

\begin{tabular}{|c|c|c|c|c|c|c|c|c|}
\hline & Poor health & Poor health & $\begin{array}{l}\text { Poor } \\
\text { healtha) }\end{array}$ & $\begin{array}{l}\text { Poor } \\
\text { healtha) }\end{array}$ & $\log$ (fibrin.) & $\log ($ fibrin.) & $\log (\mathrm{CRP})$ & $\log (\mathrm{CRP})$ \\
\hline & $\begin{array}{l}1947 \\
\text { reform } \\
\text { cohorts } \\
(1)\end{array}$ & $\begin{array}{l}1973 \\
\text { reform } \\
\text { cohorts } \\
(2)\end{array}$ & $\begin{array}{l}1947 \\
\text { reform } \\
\text { cohorts } \\
(3)\end{array}$ & $\begin{array}{l}1973 \\
\text { reform } \\
\text { cohorts } \\
(4)\end{array}$ & $\begin{array}{l}1947 \\
\text { reform } \\
\text { cohorts } \\
\text { (5) }\end{array}$ & $\begin{array}{l}1973 \\
\text { reform } \\
\text { cohorts } \\
(6)\end{array}$ & $\begin{array}{l}1947 \\
\text { reform } \\
\text { cohorts } \\
\text { (7) }\end{array}$ & $\begin{array}{l}1973 \\
\text { reform } \\
\text { cohorts } \\
(8)\end{array}$ \\
\hline \multicolumn{9}{|c|}{ Men - no controls } \\
\hline Age left school & $\begin{array}{l}-0.054^{\star \star \star} \\
(0.004)\end{array}$ & $\begin{array}{l}-0.044^{* * *} \\
(0.003)\end{array}$ & $\begin{array}{l}-0.053^{* * *} \\
(0.006)\end{array}$ & $\begin{array}{l}-0.032^{\star \star \star} \\
(0.004)\end{array}$ & $\begin{array}{l}-0.019 * * * \\
(0.003)\end{array}$ & $\begin{array}{l}-0.018^{* * *} \\
(0.003)\end{array}$ & $\begin{array}{l}-0.102^{\star \star \star} \\
(0.018)\end{array}$ & $\begin{array}{l}-0.074^{\star \star *} \\
(0.020)\end{array}$ \\
\hline Age left school & $\begin{array}{c}\text { Men - controllin } \\
-0.051^{\star \star \star} \\
(0.004)\end{array}$ & $\begin{array}{l}g \text { for birth coho } \\
-0.042^{\star \star *} \\
(0.003)\end{array}$ & $\begin{array}{l}\text { ort (year an } \\
-0.048^{\star \star *} \\
(0.006)\end{array}$ & $\begin{array}{l}\text { month), sea } \\
-0.030^{\star \star *} \\
(0.004)\end{array}$ & $\begin{array}{l}\text { of birth, he } \\
-0.015^{\star \star \star} \\
(0.003)\end{array}$ & $\begin{array}{l}\text { ght, and sur } \\
-0.016^{\star \star \star} \\
(0.003)\end{array}$ & $\begin{array}{l}\text { y year } \\
-0.102^{\star \star \star} \\
(0.019)\end{array}$ & $\begin{array}{l}-0.073^{\star * *} \\
(0.020)\end{array}$ \\
\hline $\mathrm{N}$ & 5577 & 5925 & 2735 & 3074 & 2737 & 3074 & 1611 & 1630 \\
\hline \multicolumn{9}{|c|}{ Women - no controls } \\
\hline Age left school & $\begin{array}{l}-0.063^{\star \star \star} \\
(0.004)\end{array}$ & $\begin{array}{l}-0.039 * * * \\
(0.003)\end{array}$ & $\begin{array}{l}-0.058^{* * *} \\
(0.005)\end{array}$ & $\begin{array}{l}-0.033^{\star * *} \\
(0.004)\end{array}$ & $\begin{array}{l}-0.015^{\star \star *} \\
(0.003)\end{array}$ & $\begin{array}{l}-0.021^{\star \star \star} \\
(0.003)\end{array}$ & $\begin{array}{l}-0.075^{\star \star *} \\
(0.017)\end{array}$ & $\begin{array}{l}-0.110 * * * \\
(0.018)\end{array}$ \\
\hline \multicolumn{9}{|c|}{ Women - controlling for birth cohort (year and month), season of birth, height, and survey year } \\
\hline Age left school & $\begin{array}{l}-0.059^{\star \star \star} \\
(0.004)\end{array}$ & $\begin{array}{l}-0.038^{* * *} \\
(0.003)\end{array}$ & $\begin{array}{l}-0.054^{* * *} \\
(0.005)\end{array}$ & $\begin{array}{l}-0.033^{\star * *} \\
(0.004)\end{array}$ & $\begin{array}{l}-0.011^{\star \star \star} \\
(0.003)\end{array}$ & $\begin{array}{l}-0.020 * \star \star \\
(0.003)\end{array}$ & $\begin{array}{l}-0.070^{\star \star *} \\
(0.017)\end{array}$ & $\begin{array}{l}-0.106^{\star * *} \\
(0.018)\end{array}$ \\
\hline $\mathrm{N}$ & 6199 & 7252 & 2909 & 3409 & 2911 & 3410 & 1749 & 1848 \\
\hline
\end{tabular}

Notes: Cluster corrected standard errors in parentheses; * $p<10 \%$; ${ }^{* \star} p<5 \%$; ${ }^{\star \star \star} p<1 \%$;

a) Restricted to observations with valid fibrinogen values. 
Table 4: Fuzzy regression discontinuity estimates for the effect of education on health

\begin{tabular}{|c|c|c|c|c|c|c|c|c|}
\hline & $\begin{array}{l}\text { Poor } \\
\text { health }\end{array}$ & $\begin{array}{l}\text { Poor } \\
\text { health }\end{array}$ & $\begin{array}{l}\text { Poor } \\
\text { healtha) }\end{array}$ & $\begin{array}{l}\text { Poor } \\
\text { healtha) }\end{array}$ & $\log$ (fibrin.) & $\log$ (fibrin.) & $\log (\mathrm{CRP})$ & $\log (\mathrm{CRP})$ \\
\hline & $\begin{array}{l}1947 \\
\text { reform } \\
\text { cohorts } \\
\text { (1) } \\
\end{array}$ & $\begin{array}{l}1973 \\
\text { reform } \\
\text { cohorts } \\
(2)\end{array}$ & $\begin{array}{l}1947 \\
\text { reform } \\
\text { cohorts } \\
\text { (1) }\end{array}$ & $\begin{array}{l}1973 \\
\text { reform } \\
\text { cohorts } \\
(2)\end{array}$ & $\begin{array}{l}1947 \\
\text { reform } \\
\text { cohorts } \\
(3)\end{array}$ & $\begin{array}{l}1973 \\
\text { reform } \\
\text { cohorts } \\
\text { (4) }\end{array}$ & $\begin{array}{l}1947 \\
\text { reform } \\
\text { cohorts } \\
\text { (5) }\end{array}$ & $\begin{array}{l}1973 \\
\text { reform } \\
\text { cohorts } \\
(6)\end{array}$ \\
\hline \multicolumn{9}{|l|}{ Men } \\
\hline First stage parameter & $\begin{array}{l}0.38^{* * *} \\
(0.08)\end{array}$ & $\begin{array}{l}0.33^{\star \star *} \\
(0.07)\end{array}$ & $\begin{array}{l}0.32^{\star \star \star} \\
(0.09)\end{array}$ & $\begin{array}{l}0.32^{\star * \star} \\
(0.10)\end{array}$ & $\begin{array}{l}0.33^{\star \star \star} \\
(0.09)\end{array}$ & $\begin{array}{l}0.32^{\star \star \star} \\
(0.10)\end{array}$ & $\begin{array}{l}0.40^{\star \star \star} \\
(0.14)\end{array}$ & $\begin{array}{l}0.39^{\star \star \star} \\
(0.13)\end{array}$ \\
\hline First-stage F statistic & 23.49 & 22.47 & 14.23 & 10.55 & 14.67 & 10.55 & 8.03 & 9.43 \\
\hline FRD parameter & $\begin{array}{l}0.02 \\
(0.06)\end{array}$ & $\begin{array}{l}-0.08 \\
(0.06)\end{array}$ & $\begin{array}{l}0.05 \\
(0.09)\end{array}$ & $\begin{array}{l}-0.08 \\
(0.10)\end{array}$ & $\begin{array}{l}-0.03 \\
(0.06)\end{array}$ & $\begin{array}{l}0.01 \\
(0.05)\end{array}$ & $\begin{array}{l}-0.12 \\
(0.23)\end{array}$ & $\begin{array}{l}-0.18 \\
(0.25)\end{array}$ \\
\hline Observations & 5577 & 5925 & 2735 & 3074 & 2737 & 3074 & 1611 & 1630 \\
\hline \multicolumn{9}{|l|}{ Women } \\
\hline First stage parameter & $\begin{array}{l}0.52^{\star * *} \\
(0.08)\end{array}$ & $\begin{array}{l}0.31 \text { *** } \\
(0.07)\end{array}$ & $\begin{array}{l}0.41^{\star \star \star} \\
(0.11)\end{array}$ & $\begin{array}{l}0.31 \text { *** } \\
(0.09)\end{array}$ & $\begin{array}{l}0.41 * \star * \\
(0.11)\end{array}$ & $\begin{array}{l}0.31^{\star \star \star} \\
(0.09)\end{array}$ & $\begin{array}{l}0.49^{\star \star \star} \\
(0.15)\end{array}$ & $\begin{array}{l}0.20 \\
(0.14)\end{array}$ \\
\hline First-stage F statistic & 37.39 & 17.92 & 14.59 & 10.95 & 14.53 & 11.09 & 10.24 & 1.95 \\
\hline FRD parameter & $\begin{array}{l}-0.07^{*} \\
(0.04)\end{array}$ & $\begin{array}{l}0.15^{\star *} \\
(0.06)\end{array}$ & $\begin{array}{l}-0.12 \\
(0.08)\end{array}$ & $\begin{array}{l}0.11 \\
(0.08)\end{array}$ & $\begin{array}{l}0.04 \\
(0.04)\end{array}$ & $\begin{array}{l}-0.01 \\
(0.05)\end{array}$ & $\begin{array}{l}-0.37 \\
(0.24)\end{array}$ & $\begin{array}{l}-0.09 \\
(0.49)\end{array}$ \\
\hline Observations & 6199 & 7252 & 2909 & 3409 & 2911 & 3410 & 1749 & 1848 \\
\hline
\end{tabular}

Cluster corrected standard errors in parentheses, * significant at 10\%; ** significant at 5\%; ${ }^{\star \star *}$ significant at 1\%

Controlling for year and month of birth, survey year, sex, and height

a) Restricted to observations with valid fibrinogen values 
Table 5: Fuzzy regression discontinuity estimates for the effect of education on health, various bandwidths

\begin{tabular}{|c|c|c|c|c|c|c|c|c|}
\hline & Poor health & Poor health & $\begin{array}{l}\text { Poor health } \\
\text { a) }\end{array}$ & $\begin{array}{l}\text { Poor health } \\
\text { a) }\end{array}$ & $\log$ (fibrin.) & log(fibrin.) & $\log (\mathrm{CRP})$ & $\log (\mathrm{CRP})$ \\
\hline $\begin{array}{l}\text { Bandwidth } \\
\text { (years) }\end{array}$ & $\begin{array}{l}1947 \\
\text { reform } \\
\text { cohorts } \\
\text { (1) }\end{array}$ & $\begin{array}{l}1973 \\
\text { reform } \\
\text { cohorts } \\
(2)\end{array}$ & $\begin{array}{l}1947 \\
\text { reform } \\
\text { cohorts } \\
(3)\end{array}$ & $\begin{array}{l}1973 \\
\text { reform } \\
\text { cohorts } \\
(4)\end{array}$ & $\begin{array}{l}1947 \\
\text { reform } \\
\text { cohorts } \\
\text { (5) }\end{array}$ & $\begin{array}{l}1973 \\
\text { reform } \\
\text { cohorts } \\
(6)\end{array}$ & $\begin{array}{l}1947 \\
\text { reform } \\
\text { cohorts } \\
(7)\end{array}$ & $\begin{array}{l}1973 \\
\text { reform } \\
\text { cohorts } \\
\text { (8) }\end{array}$ \\
\hline \multicolumn{9}{|l|}{ Men } \\
\hline 1 & -0.10 & 0.09 & 0.69 & 6.67 & 1.43 & 0.71 & -2.79 & 16.05 \\
\hline 1.5 & 0.02 & -0.09 & -0.13 & -0.01 & -0.10 & -0.05 & $-0.67^{\star}$ & -0.33 \\
\hline 2 & 0.04 & -0.10 & -0.13 & -0.03 & $-0.15^{\star}$ & -0.01 & -0.67 ** & -0.29 \\
\hline 2.5 & 0.06 & -0.07 & -0.03 & 0.04 & -0.09 & 0.03 & -0.40 & -0.30 \\
\hline 3 & 0.10 & -0.06 & 0.08 & 0.02 & -0.08 & 0.05 & -0.39 & -0.26 \\
\hline 3.5 & 0.07 & -0.05 & 0.11 & -0.00 & -0.06 & 0.02 & -0.29 & -0.25 \\
\hline 4 & 0.02 & -0.08 & 0.05 & -0.08 & -0.03 & 0.01 & -0.12 & -0.18 \\
\hline 4.5 & 0.02 & -0.06 & 0.09 & -0.05 & -0.01 & -0.02 & 0.05 & -0.20 \\
\hline 5 & 0.03 & -0.07 & 0.10 & -0.06 & -0.02 & -0.01 & 0.01 & -0.07 \\
\hline 5.5 & 0.02 & -0.08 & 0.11 & -0.08 & -0.00 & -0.03 & -0.02 & -0.17 \\
\hline 6 & 0.01 & -0.09 & 0.08 & -0.09 & -0.01 & -0.02 & -0.03 & -0.17 \\
\hline 6.5 & -0.00 & -0.07 & 0.09 & -0.05 & -0.01 & -0.00 & 0.03 & -0.09 \\
\hline 7 & -0.03 & -0.08 & 0.05 & -0.05 & -0.02 & -0.02 & 0.02 & -0.07 \\
\hline 7.5 & -0.03 & -0.07 & 0.05 & -0.04 & -0.02 & -0.03 & -0.02 & -0.20 \\
\hline 8 & -0.04 & -0.06 & 0.04 & -0.01 & -0.03 & -0.03 & -0.05 & -0.21 \\
\hline \multicolumn{9}{|l|}{ Women } \\
\hline 1 & 0.79 & 0.06 & 0.10 & 0.34 & 0.03 & -0.19 & 1.78 & -0.82 \\
\hline 1.5 & 0.00 & 0.07 & -0.14 & 0.03 & 0.02 & -0.01 & -0.23 & -0.73 \\
\hline 2 & 0.00 & 0.10 & -0.16 & 0.10 & 0.06 & -0.04 & -0.39 & -1.24 \\
\hline 2.5 & -0.05 & $0.13^{\star \star}$ & -0.14 & 0.20 & 0.00 & 0.06 & -0.18 & -0.70 \\
\hline 3 & -0.04 & $0.09^{*}$ & -0.11 & 0.06 & 0.00 & 0.03 & -0.21 & -0.30 \\
\hline 3.5 & -0.05 & $0.16^{\star \star}$ & -0.11 & 0.11 & 0.04 & 0.01 & -0.26 & -0.27 \\
\hline 4 & $-0.07^{\star}$ & $0.15^{\star \star}$ & -0.12 & 0.11 & 0.04 & -0.01 & -0.37 & -0.09 \\
\hline 4.5 & $-0.08^{* *}$ & $0.10^{\star *}$ & $-0.15^{\star *}$ & 0.06 & 0.03 & 0.02 & -0.23 & 0.02 \\
\hline 5 & $-0.08^{\star *}$ & 0.06 & $-0.15^{\star *}$ & 0.03 & 0.02 & 0.03 & -0.17 & 0.13 \\
\hline 5.5 & $-0.08 * *$ & $0.09 * \star$ & $-0.14^{\star *}$ & 0.05 & 0.01 & -0.01 & -0.23 & -0.00 \\
\hline 6 & -0.07 ** & $0.08^{*}$ & $-0.11^{*}$ & 0.02 & 0.00 & -0.01 & -0.21 & 0.10 \\
\hline 6.5 & $-0.06^{\star *}$ & $0.09 *$ & $-0.10^{*}$ & 0.02 & -0.01 & -0.00 & -0.20 & 0.06 \\
\hline 7 & $-0.06^{\star *}$ & $0.09^{*}$ & $-0.10^{\text {** }}$ & 0.04 & -0.02 & 0.01 & -0.20 & 0.07 \\
\hline 7.5 & $-0.07^{* * *}$ & 0.08 & $-0.11^{* *}$ & 0.04 & -0.02 & 0.01 & -0.19 & 0.19 \\
\hline 8 & $-0.07^{* * *}$ & 0.08 & $-0.09 * *$ & 0.06 & -0.02 & 0.02 & -0.22 & 0.44 \\
\hline
\end{tabular}

Cluster corrected standard errors in parentheses; * $p<10 \%$; ${ }^{\star \star} p<5 \%$; ${ }^{\star \star \star} p<1 \%$;

Controlling for month of birth cohort, survey year, season of birth, and height

a) Restricted to observations with valid fibrinogen values 
Table 6: Fuzzy regression discontinuity estimates for the effect of education on health, various polynomial trends (k) and bandwidths (h)

\begin{tabular}{|c|c|c|c|c|c|c|c|c|}
\hline & Poor health & Poor health & $\begin{array}{l}\text { Poor health } \\
\text { a) }\end{array}$ & $\begin{array}{l}\text { Poor health } \\
\text { a) }\end{array}$ & $\log$ (fibrin.) & log(fibrin.) & $\log (\mathrm{CRP})$ & $\log (\mathrm{CRP})$ \\
\hline $\begin{array}{l}\text { Polynomial, } \\
\text { Bandwidth }\end{array}$ & $\begin{array}{l}1947 \\
\text { reform } \\
\text { cohorts } \\
(1)\end{array}$ & $\begin{array}{l}1973 \\
\text { reform } \\
\text { cohorts } \\
(2)\end{array}$ & $\begin{array}{l}1947 \\
\text { reform } \\
\text { cohorts } \\
(3)\end{array}$ & $\begin{array}{l}1973 \\
\text { reform } \\
\text { cohorts } \\
\text { (4) }\end{array}$ & $\begin{array}{l}1947 \\
\text { reform } \\
\text { cohorts } \\
\text { (5) }\end{array}$ & $\begin{array}{l}1973 \\
\text { reform } \\
\text { cohorts } \\
(6)\end{array}$ & $\begin{array}{l}1947 \\
\text { reform } \\
\text { cohorts } \\
(7)\end{array}$ & $\begin{array}{l}1973 \\
\text { reform } \\
\text { cohorts } \\
\text { (8) }\end{array}$ \\
\hline \multicolumn{9}{|l|}{ Men } \\
\hline$k=1, h=4$ & 0.02 & -0.08 & 0.05 & -0.08 & -0.03 & 0.01 & -0.12 & -0.19 \\
\hline$k=2, h=4$ & 0.02 & -0.08 & 0.05 & -0.08 & -0.03 & 0.01 & -0.12 & -0.18 \\
\hline$k=3, h=4$ & 0.12 & -0.06 & 0.03 & 0.10 & -0.11 & 0.03 & -0.64 & -0.39 \\
\hline $\mathrm{k}=4, \mathrm{~h}=4$ & 0.12 & -0.06 & 0.04 & 0.10 & -0.11 & 0.03 & -0.64 & -0.39 \\
\hline$k=1, h=8$ & -0.04 & -0.07 & 0.04 & -0.01 & -0.03 & -0.03 & -0.05 & -0.23 \\
\hline$k=2, h=8$ & -0.04 & -0.06 & 0.04 & -0.01 & -0.03 & -0.03 & -0.06 & -0.22 \\
\hline$k=3, h=8$ & 0.04 & $-0.09 *$ & 0.11 & -0.08 & 0.01 & -0.02 & 0.02 & -0.14 \\
\hline$k=4, h=8$ & 0.04 & $-0.09^{*}$ & 0.11 & -0.08 & 0.01 & -0.02 & 0.02 & -0.14 \\
\hline \multicolumn{9}{|l|}{ Women } \\
\hline $\mathrm{k}=1, \mathrm{~h}=4$ & $-0.07^{*}$ & $0.15^{\star \star}$ & -0.12 & 0.11 & 0.04 & -0.01 & -0.37 & -0.10 \\
\hline$k=2, h=4$ & $-0.07^{*}$ & $0.15^{\star \star}$ & -0.12 & 0.11 & 0.04 & -0.01 & -0.36 & -0.09 \\
\hline$k=3, h=4$ & -0.02 & 0.12 & -0.13 & 0.12 & 0.02 & 0.03 & -0.15 & -0.66 \\
\hline $\mathrm{k}=4, \mathrm{~h}=4$ & -0.02 & 0.12 & -0.13 & 0.12 & 0.02 & 0.03 & -0.16 & -0.64 \\
\hline$k=1, h=8$ & $-0.07^{\star \star \star}$ & 0.08 & $-0.09 * *$ & 0.06 & -0.02 & 0.02 & -0.22 & 0.39 \\
\hline$k=2, h=8$ & $-0.07^{\star \star \star}$ & 0.08 & $-0.09 * *$ & 0.06 & -0.02 & 0.02 & -0.22 & 0.44 \\
\hline$k=3, h=8$ & $-0.06^{*}$ & 0.10 ** & $-0.16^{\star *}$ & 0.03 & 0.01 & -0.01 & -0.20 & -0.16 \\
\hline$k=4, h=8$ & $-0.06^{*}$ & 0.10 ** & $-0.16^{\star *}$ & 0.03 & 0.01 & -0.01 & -0.20 & -0.16 \\
\hline
\end{tabular}

Cluster corrected standard errors in parentheses; * $p<10 \%$; ${ }^{\star \star} p<5 \%$; ${ }^{\star \star \star} p<1 \%$;

Controlling for survey year and height, season of birth

a) Restricted to observations with valid fibrinogen values 
Table 7: Fuzzy regression discontinuity estimates for the effect of education on health (restricted samples)

\begin{tabular}{|c|c|c|c|c|c|c|c|c|}
\hline & $\begin{array}{l}\text { Poor } \\
\text { health }\end{array}$ & $\begin{array}{l}\text { Poor } \\
\text { health }\end{array}$ & $\begin{array}{l}\text { Poor } \\
\text { healtha) }\end{array}$ & $\begin{array}{l}\text { Poor } \\
\text { healtha) }\end{array}$ & $\log ($ fibrin.) & $\log ($ fibrin.) & $\log (\mathrm{CRP})$ & $\log (\mathrm{CRP})$ \\
\hline & $\begin{array}{l}1947 \\
\text { reform } \\
\text { cohorts } \\
\text { (1) }\end{array}$ & $\begin{array}{l}1973 \\
\text { reform } \\
\text { cohorts } \\
(2)\end{array}$ & $\begin{array}{l}1947 \\
\text { reform } \\
\text { cohorts } \\
\text { (1) }\end{array}$ & $\begin{array}{l}1973 \\
\text { reform } \\
\text { cohorts } \\
\text { (2) }\end{array}$ & $\begin{array}{l}1947 \\
\text { reform } \\
\text { cohorts } \\
\text { (3) }\end{array}$ & $\begin{array}{l}1973 \\
\text { reform } \\
\text { cohorts } \\
\text { (4) }\end{array}$ & $\begin{array}{l}1947 \\
\text { reform } \\
\text { cohorts } \\
(5)\end{array}$ & $\begin{array}{l}1973 \\
\text { reform } \\
\text { cohorts } \\
(6)\end{array}$ \\
\hline \multicolumn{9}{|l|}{ Men } \\
\hline OLS parameter & $\begin{array}{l}-0.067^{\star * *} \\
(0.021)\end{array}$ & $\begin{array}{l}-0.086^{\star \star \star} \\
(0.019)\end{array}$ & $\begin{array}{l}-0.050 * \\
(0.030)\end{array}$ & $\begin{array}{l}-0.080 * \star * \\
(0.022)\end{array}$ & $\begin{array}{l}-0.023 \\
(0.015)\end{array}$ & $\begin{array}{l}-0.031^{* *} \\
(0.015)\end{array}$ & $\begin{array}{l}-0.194^{\star \star \star} \\
(0.073)\end{array}$ & $\begin{array}{l}-0.169 * * \\
(0.070)\end{array}$ \\
\hline IV First stage parameter & $\begin{array}{l}0.63^{\star \star \star} \\
(0.03)\end{array}$ & $\begin{array}{l}0.33^{\star * \star} \\
(0.03)\end{array}$ & $\begin{array}{l}0.67^{\star \star *} \\
(0.03)\end{array}$ & $\begin{array}{l}0.30^{\star \star \star} \\
(0.04)\end{array}$ & $\begin{array}{l}0.67^{\star * *} \\
(0.03)\end{array}$ & $\begin{array}{l}0.30^{\star * *} \\
(0.04)\end{array}$ & $\begin{array}{l}0.74^{\star \star \star} \\
(0.04)\end{array}$ & $\begin{array}{l}0.34^{\star \star \star} \\
(0.06)\end{array}$ \\
\hline First-stage F statistic & 499.92 & 111.48 & 417.41 & 49.26 & 422.46 & 49.26 & 365.18 & 30.42 \\
\hline FRD parameter & $\begin{array}{l}-0.02 \\
(0.05)\end{array}$ & $\begin{array}{l}-0.10 \\
(0.09)\end{array}$ & $\begin{array}{l}-0.03 \\
(0.06)\end{array}$ & $\begin{array}{l}-0.07 \\
(0.14)\end{array}$ & $\begin{array}{l}-0.03 \\
(0.04)\end{array}$ & $\begin{array}{l}0.06 \\
(0.08)\end{array}$ & $\begin{array}{l}-0.12 \\
(0.19)\end{array}$ & $\begin{array}{l}0.32 \\
(0.41)\end{array}$ \\
\hline Observations & 3690 & 3496 & 1790 & 1800 & 1792 & 1800 & 1077 & 965 \\
\hline \multicolumn{9}{|l|}{ Women } \\
\hline OLS parameter & $\begin{array}{l}-0.086^{\star \star *} \\
(0.021)\end{array}$ & $\begin{array}{l}-0.083^{\star \star *} \\
(0.017)\end{array}$ & $\begin{array}{l}-0.079 * * \\
(0.031)\end{array}$ & $\begin{array}{l}-0.110^{* * *} \\
(0.022)\end{array}$ & $\begin{array}{l}-0.013 \\
(0.015)\end{array}$ & $\begin{array}{l}-0.015 \\
(0.014)\end{array}$ & $\begin{array}{l}-0.123 \\
(0.079)\end{array}$ & $\begin{array}{l}-0.213^{\star *} \\
(0.092)\end{array}$ \\
\hline IV First stage parameter & $\begin{array}{l}0.63^{\star \star \star} \\
(0.02)\end{array}$ & $\begin{array}{l}0.41^{\star * *} \\
(0.03)\end{array}$ & $\begin{array}{l}0.59 * \star \star \\
(0.04)\end{array}$ & $\begin{array}{l}0.43^{\star \star \star} \\
(0.03)\end{array}$ & $\begin{array}{l}0.59 * * * \\
(0.04)\end{array}$ & $\begin{array}{l}0.43^{\star \star \star} \\
(0.03)\end{array}$ & $\begin{array}{l}0.62^{\star \star \star} \\
(0.05)\end{array}$ & $\begin{array}{l}0.41^{\star \star \star} \\
(0.04)\end{array}$ \\
\hline First-stage F statistic & 741.47 & 190.28 & 269.84 & 161.49 & 270.34 & 161.49 & 181.49 & 91.69 \\
\hline FRD parameter & $\begin{array}{l}-0.03 \\
(0.06)\end{array}$ & $\begin{array}{l}0.15^{\star \star \star} \\
(0.05)\end{array}$ & $\begin{array}{l}-0.04 \\
(0.09)\end{array}$ & $\begin{array}{l}0.08 \\
(0.08)\end{array}$ & $\begin{array}{l}0.03 \\
(0.03)\end{array}$ & $\begin{array}{l}-0.06 \\
(0.05)\end{array}$ & $\begin{array}{l}-0.30 \\
(0.19)\end{array}$ & $\begin{array}{l}-0.27 \\
(0.33)\end{array}$ \\
\hline Observations & 4009 & 4064 & 1815 & 1892 & 1817 & 1892 & 1059 & 1009 \\
\hline
\end{tabular}

Cluster corrected standard errors in parentheses, * significant at 10\%; ** significant at 5\%; ${ }^{* \star}$ significant at 1\%

Controlling for year and month of birth, survey year, sex, and height

a) Restricted to observations with valid fibrinogen values 
Table A1: Probit regressions explaining non-refusal to nurse visit and blood sample, marginal effects

\begin{tabular}{|c|c|c|c|c|}
\hline & \multicolumn{2}{|l|}{1947 reform cohort } & \multicolumn{2}{|l|}{1973 reform cohort } \\
\hline & Agree to nurse visit & $\begin{array}{l}\text { Agree to blood } \\
\text { sample }\end{array}$ & Agree to nurse visit & $\begin{array}{l}\text { Agree to blood } \\
\text { sample }\end{array}$ \\
\hline Age (in years) & $\begin{array}{l}0.002 \\
(0.004)\end{array}$ & $\begin{array}{l}-0.005 \\
(0.004)\end{array}$ & $\begin{array}{l}0.004 \\
(0.003)\end{array}$ & $\begin{array}{l}0.005 \\
(0.003)\end{array}$ \\
\hline Female & $\begin{array}{l}-0.001 \\
(0.013)\end{array}$ & $\begin{array}{l}-0.025^{\star} \\
(0.013)\end{array}$ & $\begin{array}{l}-0.023^{\star} \\
(0.011)\end{array}$ & $\begin{array}{l}-0.015 \\
(0.011)\end{array}$ \\
\hline Age left school & $\begin{array}{l}-0.001 \\
(0.005)\end{array}$ & $\begin{array}{l}-0.005 \\
(0.005)\end{array}$ & $\begin{array}{l}0.002 \\
(0.004)\end{array}$ & $\begin{array}{l}0.011^{\star *} \\
(0.004)\end{array}$ \\
\hline Good health & $\begin{array}{l}0.011 \\
(0.014)\end{array}$ & $\begin{array}{l}0.087^{* *} \\
(0.015)\end{array}$ & $\begin{array}{l}0.008 \\
(0.016)\end{array}$ & $\begin{array}{l}0.042^{\star} \\
(0.017)\end{array}$ \\
\hline Year 1998 & $\begin{array}{l}-0.040 \\
(0.025)\end{array}$ & $\begin{array}{l}-0.006 \\
(0.024)\end{array}$ & $\begin{array}{l}-0.039 \\
(0.020)\end{array}$ & $\begin{array}{l}-0.048^{\star} \\
(0.019)\end{array}$ \\
\hline Year 1999 & $\begin{array}{l}-0.264^{\star *} \\
(0.066)\end{array}$ & $\begin{array}{l}0.004 \\
(0.046)\end{array}$ & $\begin{array}{l}-0.183^{\star *} \\
(0.041)\end{array}$ & $\begin{array}{l}-0.037 \\
(0.034)\end{array}$ \\
\hline Year 2000 & $\begin{array}{l}-0.032 \\
(0.036)\end{array}$ & $\begin{array}{l}-0.065 \\
(0.040)\end{array}$ & & \\
\hline Observations & 2890 & 2506 & 3352 & 2937 \\
\hline Average percentage & 86.7 & 87.7 & 87.6 & 90.4 \\
\hline $\begin{array}{l}\text { Chi-squared test for health } \\
\text { and demographics }\end{array}$ & 1.02 & $42.35^{\star \star}$ & 6.03 & $20.88^{* *}$ \\
\hline
\end{tabular}

Standard errors in parentheses; * significant at 5\%; ** significant at $1 \%$ 


\section{Effect of 1947 reform on school leaving age}
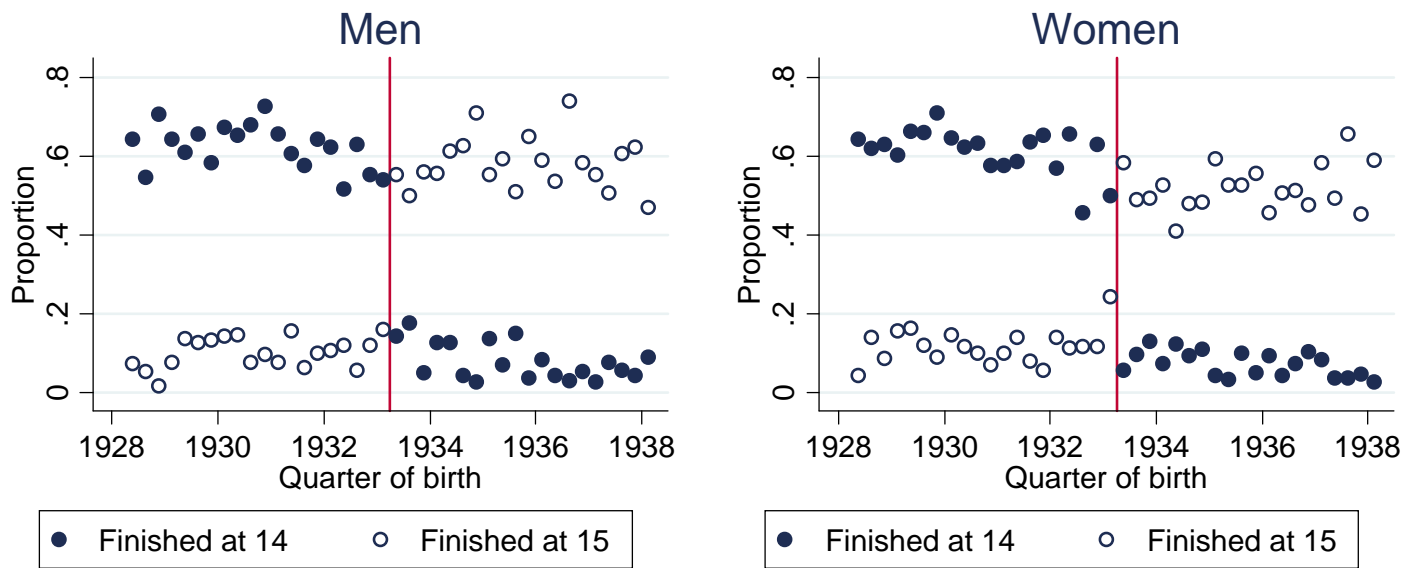

\section{Effect of 1973 reform on school leaving age}
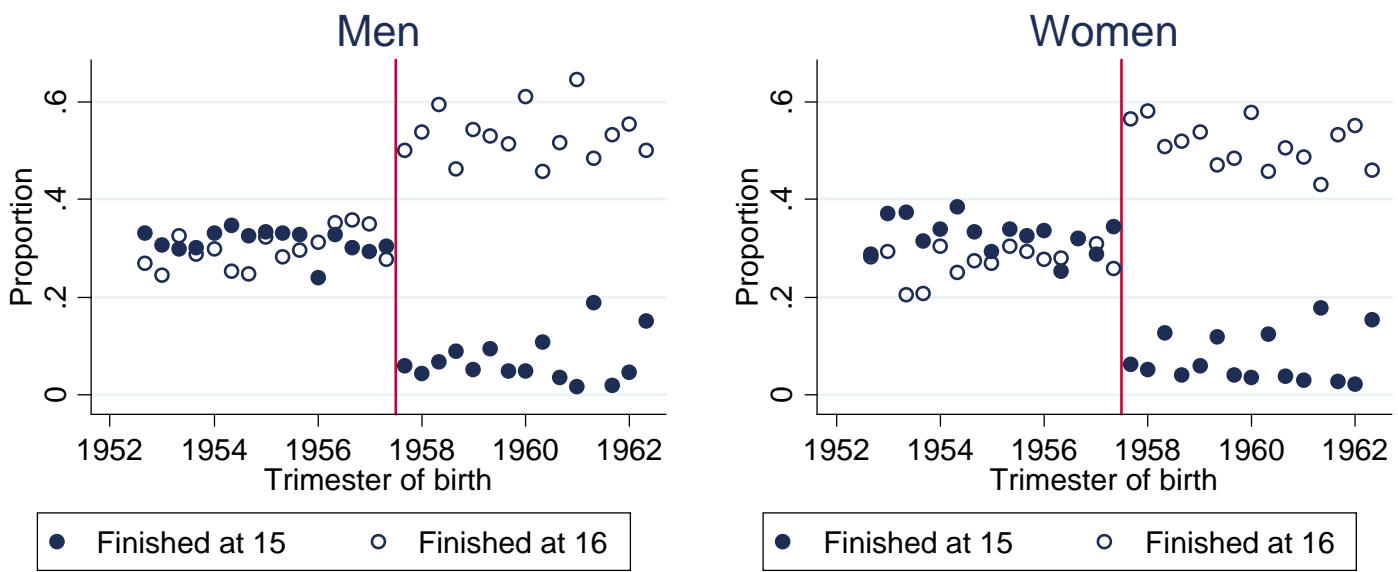

Figure 1: Effect of the 1947 and 1973 changes in compulsory school leaving age on educational attainment, measured by the proportion of respondents who left school at ages 14, 15 or 16 , respectively. 
Effect of 1947 reform on school leaving age
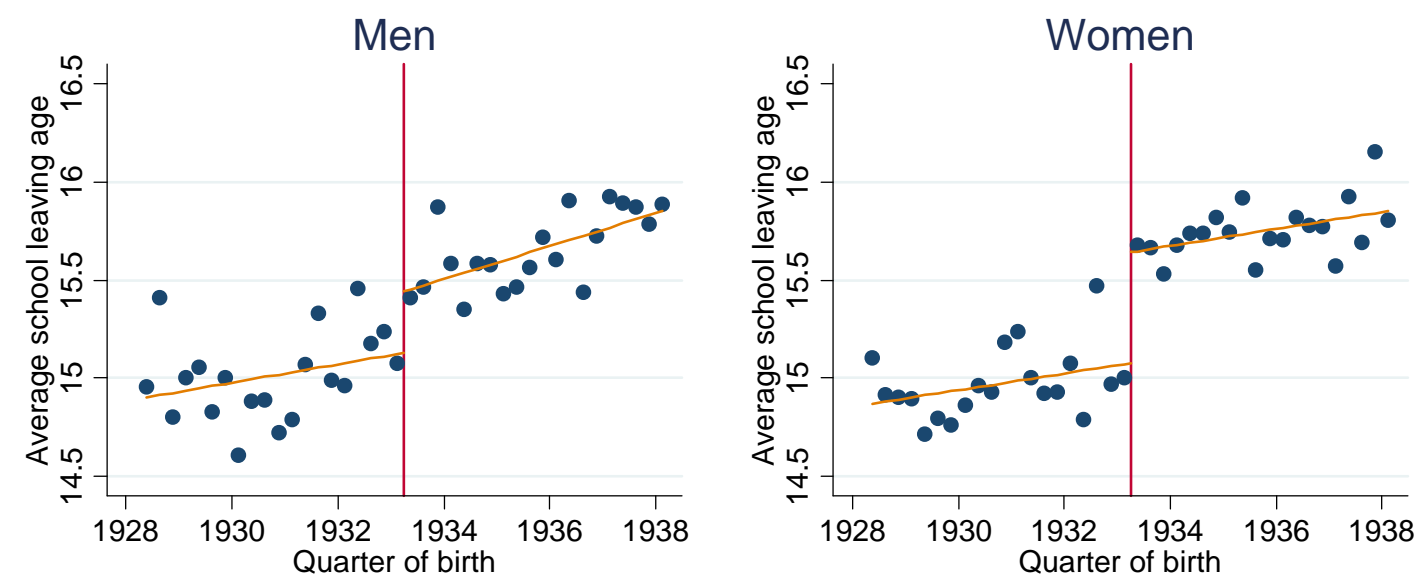

Effect of 1973 reform on school leaving age
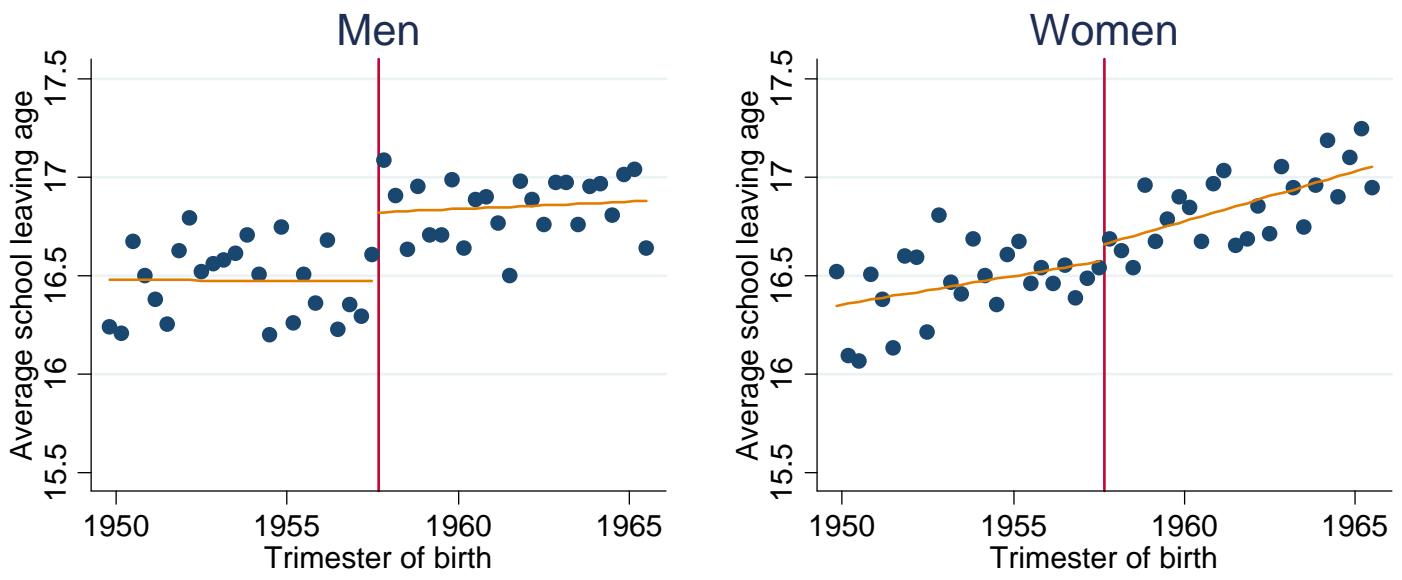

Figure 2: Effect of the 1947 and 1973 changes in compulsory school leaving age on educational attainment, measured by the average school leaving age. 


\section{Discussion Paper Series}

Mannheim Research Institute for the Economics of Aging, Universität Mannheim

To order copies, please direct your request to the author of the title in question.

\begin{tabular}{|c|c|c|c|}
\hline Nr. & Autoren & Titel & Jahr \\
\hline $171-08$ & \begin{tabular}{|l|} 
Johannes Binswanger \\
Daniel Schunk
\end{tabular} & $\begin{array}{l}\text { What Is an Adequate Standard of Living } \\
\text { during Retirement? }\end{array}$ & 08 \\
\hline $172-08$ & $\begin{array}{l}\text { Mathis Schröder } \\
\text { Axel Börsch-Supan }\end{array}$ & Retrospective Data Collection in Europe & 08 \\
\hline $173-09$ & Michael Ziegelmeyer & $\begin{array}{l}\text { Documentation of the logical imputation using } \\
\text { the panel structure of the 2003-2008 German } \\
\text { SAVE Survey }\end{array}$ & 09 \\
\hline $174-09$ & \begin{tabular}{|l|} 
Axel Börsch-Supan, \\
Tabea Bucher-Koenen, \\
Martin Gasche und \\
Christina Benita Wilke
\end{tabular} & $\begin{array}{l}\text { Ein einheitliches Rentensystem für } \\
\text { Ost- und Westdeutschland - } \\
\text { Simulationsrechnungen zum Reformvorschlag } \\
\text { des Sachverständigenrates }\end{array}$ & 09 \\
\hline $175-09$ & $\begin{array}{l}\text { Steffen Reinhold, } \\
\text { Hendrik Jürges }\end{array}$ & Parental Income and Child Health in Germany & 09 \\
\hline $176-09$ & $\begin{array}{l}\text { Karsten Hank, Marcel } \\
\text { Erlinghagen }\end{array}$ & $\begin{array}{l}\text { Perceptions of Job Security in Europe's Ageing } \\
\text { Workforce }\end{array}$ & 09 \\
\hline $177-09$ & $\begin{array}{l}\text { Hendrik Jürges, } \\
\text { Karsten Hank, }\end{array}$ & $\begin{array}{l}\text { The Last Year of Life in Europe: Initial findings } \\
\text { from the SHARE study }\end{array}$ & 09 \\
\hline $178-09$ & Steffen Reinhold & $\begin{array}{l}\text { Reassessing the Link between Premarital } \\
\text { Cohabitation and Marital Instability }\end{array}$ & 09 \\
\hline $179-09$ & $\begin{array}{l}\text { Alexander Ludwig, } \\
\text { Edgar Vogel }\end{array}$ & $\begin{array}{l}\text { Mortality, Fertility, Education and Capital } \\
\text { Accumulation in a simple OLG Economy }\end{array}$ & 09 \\
\hline $180-09$ & Edgar Vogel & $\begin{array}{l}\text { From Malthus to Modern Growth: Child Labor, } \\
\text { Schooling and Human Capital }\end{array}$ & 09 \\
\hline $181-09$ & $\begin{array}{l}\text { Steffen Reinhold, } \\
\text { Hendrik Jürges }\end{array}$ & $\begin{array}{l}\text { Secondary School Fees and the Causal Effect } \\
\text { of Schooling on Health Behaviour }\end{array}$ & 09 \\
\hline $182-09$ & $\begin{array}{l}\text { Steffen Reinhold, } \\
\text { Kevin Thom }\end{array}$ & $\begin{array}{l}\text { Temporary Migration and Skill Upgrading: } \\
\text { Evidence from Mexican Migrants }\end{array}$ & 09 \\
\hline $183-09$ & $\begin{array}{l}\text { Hendrik Jürges, } \\
\text { Eberhard Kruk, Steffen } \\
\text { Reinhold }\end{array}$ & $\begin{array}{l}\text { The effect of compulsory schooling on health - } \\
\text { evidence from biomarkers }\end{array}$ & 09 \\
\hline
\end{tabular}

